\title{
Implementation of a process-based catchment model in a poorly gauged, highly glacierized Himalayan headwater
}

\author{
M. Konz ${ }^{1}$, S. Uhlenbrook ${ }^{2}$, L. Braun ${ }^{3}$, A. Shrestha ${ }^{4}$, and S. Demuth ${ }^{5,6}$ \\ ${ }^{1}$ University of Basel, Department of Environmental Sciences, Applied and Environmental Geology, Basel, Switzerland \\ ${ }^{2}$ UNESCO-IHE, Department of Water Engineering, Delft, The Netherlands \\ ${ }^{3}$ Bavarian Academy of Sciences, Commission of Glaciology, Munich, Germany \\ ${ }^{4}$ Department of Hydrology and Meteorology, Snow and Glacier Hydrology Unit, Katmandu, Nepal \\ ${ }^{5}$ University of Freiburg, Institute of Hydrology, Freiburg, Germany \\ ${ }^{6}$ IHP/HWRP Secretariat, Federal Institute of Hydrology, Koblenz, Germany
}

Received: 31 October 2006 - Published in Hydrol. Earth Syst. Sci. Discuss.: 13 November 2006

Revised: 5 April 2007 - Accepted: 25 April 2007 - Published: 15 May 2007

\begin{abstract}
The paper presents a catchment modeling approach for remote glacierized Himalayan catchments. The distributed catchment model $\mathrm{TAC}^{\mathrm{D}}$, which is widely based on the HBV model, was further developed for the application in highly glacierized catchments on a daily timestep and applied to the Nepalese Himalayan headwater Langtang Khola $\left(360 \mathrm{~km}^{2}\right)$. Low laying reference stations are taken for temperature extrapolation applying a second order polynomial function. Probability based statistical methods enable bridging data gaps in daily precipitation time series and the redistribution of cumulated precipitation sums over the previous days. Snow and ice melt was calculated in a distributed way based on the temperature-index method employing calculated daily potential sunshine durations. Different melting conditions of snow and ice and melting of ice under debris layers were considered. The spatial delineation of hydrological response units was achieved by taking topographic and physiographic information from maps and satellite images into account, and enabled to incorporate process knowledge into the model. Simulation results demonstrated that the model is able to simulate daily discharge for a period of 10 years and point glacier mass balances observed in the research area with an adequate reliability. The simple but robust data pre-processing and modeling approach enables the determination of the components of the water balance of a remote, data scarce catchment with a minimum of input data.
\end{abstract}

Correspondence to: $\mathrm{M}$. Konz

(markus.konz@stud.unibas.ch)

\section{Introduction}

The prediction of runoff from Himalayan headwaters is a crucial element for sustainable development of the Himalayan countries (e.g. Tarar, 1982; Kattelmann, 1993; Viviroli et al., 2004). Therefore, in 1987 the German Agency for Technical Cooperation (GTZ) initiated a project to quantify climatological and hydrological conditions of Himalayan headwaters in Nepal (Grabs and Pokhrel, 1993). Today, the Department of Hydrology and Meteorology (DHM) is responsible for data collection and maintenance of the stations. Daily readings of temperature, precipitation and discharge data are outsourced to local farmers living close to the stations. DHM is doing emergency field trips and regular trips to ensure the reliability of the measurements. In spite of these efforts data losses occur due to inaccessibility of the catchment because of the weather conditions. However, these data are unique sources for the assessment of water resources of high $\mathrm{Hi}$ malayan catchments. One way to improve water resources assessment is to combine existing field data with adequate modelling approaches, as this has been done in temperate climate study areas (e.g. Uhlenbrook and Leibundgut 2002). Simulation of snow and ice melt and its impact on the water balance of a catchment is of vital interest of the scientific community (Verbunt et al., 2003). Sophisticated, data intensive models have been developed for distributed modeling of glaciated catchments (e.g. Klok et al., 2001). However, classical approaches to simulate snow and ice melt, like the application of the temperature-index method, are still used because of its robustness especially in data scarce regions (Hock, 2003; Zappa et al., 2003). First simulations of daily discharge of the Nepalese Himalayan Langtang Khola catchment were conducted by Braun et al. (1993) using a

Published by Copernicus Publications on behalf of the European Geosciences Union. 


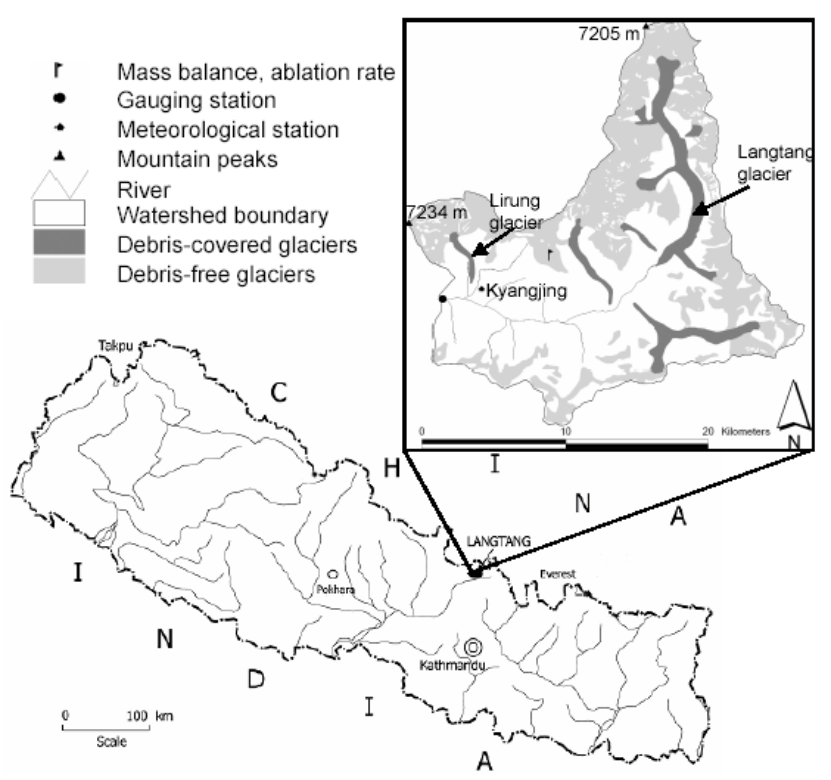

Fig. 1. Nepal and the Langtang Khola catchment.

conceptual precipitation-runoff model. In this study the authors had to apply a constant daily value to simulate the relatively high winter discharge. The value was found by calibration and added to the calculated daily runoff value. It turned out that with the lumped runoff routine of the model it was not possible to simulate the annual course of the hydrograph without this synthetic adjustment.

The catchment model $\mathrm{TAC}^{\mathrm{D}}$ (tracer aided catchment model, distributed) which was originally developed for basins in the Black Forest Mountains, Germany (Uhlenbrook et al., 2004; Ott and Uhlenbrook, 2004) was further developed for the Himalayan conditions. It is a fully distributed, modular catchment model, which at its core has a processbased runoff generation routine based on dominant process conceptualizations.

Since data availability is limited in remote Himalayan headwaters suitable ways to regionalize input data and to conceptualize the dominant runoff generation processes have to be developed. The paper describes the first application of this process-based model to a high mountain environment with very limited data and an added glacier module. The specific objectives are to describe the entire simulation procedure that consists of $(i)$ input data pre-processing to bridge gaps in time series of precipitation and temperature, (ii) the delineation of hydrological response units based on topographic and physiographic data, and (iii) the process-based runoff modeling itself. The results of this approach are illustrated for the Langtang Khola catchment in Nepal, and discussed with respect to process-based catchment modeling. The methods for input data preparation are described in detail with the relatively good data set of the Langtang Khola catchment to demonstrate the suitability and applica-
Table 1. Main characteristics of the investigated catchment during the investigation period 1987-1998.

\begin{tabular}{lcc}
\hline Area & & \\
\hline Total & $\left(\mathrm{km}^{2}\right)$ & 360.0 \\
Glacierized & $\left(\mathrm{km}^{2} / \%\right)$ & $166.1 / 46.1$ \\
$\begin{array}{l}\text { Debris-covered glacier } \\
\text { Altitudes }\end{array}$ & $\left(\mathrm{km}^{2} / \%\right)$ & $32.1 / 19.3^{1}$ \\
Range & & \\
Average & $(\mathrm{m}$ a.s.l. $)$ & $3800-7234$ \\
Exposition & $(\mathrm{m}$ a.s.l. $)$ & 5169 \\
North $^{2}$ & & \\
South & $(\%)$ & 21.3 \\
East, West, Horizontal & 4.96 \\
Mean slope & $(\%)$ & 26.8 \\
Land cover & $\left({ }^{\circ}\right)$ & 26.7 \\
Glacier & & \\
Barren land & $\left(\mathrm{km}^{2} / \%\right)$ & $166.1 / 46.1$ \\
Forest & $\left(\mathrm{km}^{2} / \%\right)$ & $183.8 / 51.1$ \\
Grass land & $\left(\mathrm{km}^{2} / \%\right)$ & $2.1 / 0.6$ \\
Others & $\left(\mathrm{km}^{2} / \%\right)$ & $3.4 / 0.9$ \\
& $\left(\mathrm{~km}^{2} / \%\right)$ & $4.6 / 1.3$ \\
\hline
\end{tabular}

1 in percent of glacier-covered area

$2315^{\circ}-45^{\circ}$

$3135^{\circ}-225^{\circ}$

$45^{\circ}-135^{\circ}$ and $225^{\circ}-315^{\circ}$

bility of the methods. The aim was to develop tools that are in principal applicable to much less intensively observed basins (poorly gauged or ungauged basins) then the Langtang Khola catchment.

\section{Study site}

The $360 \mathrm{~km}^{2}$ high mountain Himalayan Langtang Khola headwater is located approx. $100 \mathrm{~km}$ north of Katmandu (Fig. 1, Table 1). The catchment reaches from $3800 \mathrm{~m}$ a.s.l. up to the Langtang Lirung at $7234 \mathrm{~m}$ a.s.l. with two other peaks above $7000 \mathrm{~m}$ a.s.l.

The average altitude is $5169 \mathrm{~m}$ a.s.l., $166 \mathrm{~km}^{2}$ (46\%) of the $360 \mathrm{~km}^{2}$ catchment area are occupied by glaciers of which $32 \mathrm{~km}^{2}(19 \%)$ are covered by debris, especially the glacier tongues below $5200 \mathrm{~m}$ a.s.l. The glacier area is different to the one published in Braun et al. (1993) where glacier area was determined to be $38 \%$. They derived the glacier area from the DAV map (Alpenvereinskartographie, 1990), whereas in this paper the glacier inventory of the International Center of Integrated Mountain Development (ICIMOD), Katmandu, Nepal (UNEP/ICIMOD, 2002) was used.

The main valley is dissected by the Langtang Khola River and it is typically U-shaped. Table 1 summarizes the main characteristics of the investigation area. Several sets of moraines occupy the valley bottom, which have been 
attributed to the Little Ice Age, Neoglacial and Late glacial (Heuberger et al., 1984; Ono, 1986). Boulders and scree cover the steep slopes and high plateaus, while the occurrence of forest and grassland in the lower altitudes with less steep slopes along the river is limited to $1.5 \%$ of the catchment area. The riverbed consists of sand and gravel. The area is part of the Main Central Thrust Zone, and its geology consists of granite, gneiss and schist. Detailed soil information is not available for the catchment.

The characteristic feature of the climate of Nepal is the monsoon circulation with predominant easterly winds in the summer and westerly winds from October to May. In the Langtang Khola catchment, $74 \%$ of annual precipitation of $615 \mathrm{~mm} \mathrm{a}^{-1}$ at the Kyangjing station (3920 m a.s.l., Fig. 1) of the Snow and Glacier Hydrology Unit (SGHU) of the Department of Hydrology and Meteorology (DHM) falls during monsoon season (May till October; mean over period from 1988 to 1998). From June to August total precipitation amounts are large and precipitation occurs almost every day. However, the daily amount generally does not exceed $20 \mathrm{~mm} \mathrm{~d}^{-1}$. In the later part of the monsoon season (September to October) the maximum daily amount is considerably higher, while the number of rainy days decreases gradually compared to previous months. In dry season (November to May), precipitation (mainly snow) occurs on only a few days, it is produced by the occasional passage of westerly troughs ("western disturbances"; Ramage, 1971). In general, the precipitation amounts increase with altitude during both the monsoon and the dry season (Seko, 1987).

Mean daily air temperature is $0.2^{\circ} \mathrm{C}$ from October to June, and $8.4^{\circ} \mathrm{C}$ during the monsoon season at the meteorological station (3920 m a.s.1.; Fig. 1). The long-term mean of air temperature amounts to $1.8{ }^{\circ} \mathrm{C}$ for the period 1988 to 1998 (Konz et al., 2006a). Shiraiwa et al. (1992) reported mean monthly air temperatures of approximately $-10^{\circ} \mathrm{C}$ during winter periods at three temporary stations in the valley at altitudes between $5090 \mathrm{~m}$ a.s.l. and $5180 \mathrm{~m}$ a.s.l. and different expositions during their investigation period from June 1989 to March 1991. Air temperature shows distinct altitude dependence with a mean annual air temperature from June 1989 to March 1991 of $1.9^{\circ} \mathrm{C}$ at the SGHU station and $-3.5^{\circ} \mathrm{C}$ in $5090 \mathrm{~m}$ a.s.l. A mean annual elevation gradient can be estimated as $-0.46^{\circ} \mathrm{C} 100 \mathrm{~m}^{-1}$ (Shiraiwa et al., 1992). Sakai et al. (2004) observed a lapse rate of $-0.5^{\circ} \mathrm{C} 100 \mathrm{~m}^{-1}$ for the monsoon season 1996.

The discharge regime can be classified as glacial with maximum discharges in July and August and minimum discharges during the winter season. Winter discharge is characterized by a rather constant base flow with negligible inflows of rainwater or melt water as the air temperature is generally below the melting point. The mean discharge from December to the end of April is $2.8 \mathrm{~m}^{3} \mathrm{~s}^{-1}$ which constitutes about $17 \%$ of the annual discharge (Konz et al., 2006a).
Table 2. Summary of DHM reference stations in the Langtang region used for data processing ( $P$ : precipitation, $T$ : temperature).

\begin{tabular}{lcc}
\hline Station & Elevation (m a.s.l.) & Measurements \\
\hline Timure & 1900 & $P$ \\
Sarmathang & 2625 & $P$ \\
Kathmandu Airport & 1336 & $T, P$ \\
Thamachit & 1847 & $P$ \\
Paigutary & unknown & $P$ \\
Dhunche & 1982 & $T, P$ \\
Tarke Ghyang & 2480 & $P$ \\
\hline
\end{tabular}

\section{Data}

\subsection{Preparation of input data}

There is only one meteorological station in the Langtang Khola catchment at $3920 \mathrm{~m}$ a.s.l. Air temperature is measured and analyzed in $6 \mathrm{~h}$ intervals and published as maximum, minimum and mean daily air temperature. Precipitation is read manually and published as daily totals in yearbooks by the Ministry of Science and Technology, Department of Hydrology and Meteorology (DHM), Katmandu, Nepal. The data base for this study is the period 19871997 as further data are not available or of unreliable quality. Intensive quality analyses of temperature and precipitation time series were conducted for each year under investigation. Daily air temperature data are available for $98 \%$ and daily sums of precipitation are available for $93 \%$ of the days during the investigation period. Most of the missing values occur during the dry season. For some of the data gaps of the precipitation time series sums over several days were recorded instead of daily values. Appropriate procedures to fill the missing values and to redistribute cumulated precipitation sums over the previous days had to be found based on records of reference stations of the Standard Data Meteorological Service Network of DHM in the vicinity (up to $60 \mathrm{~km}$ away from the catchment) of the Langtang valley. Table 2 summarizes the reference stations with elevation and conducted measurements. The approaches are also applicable to catchments with worse data availability then the Langtang Khola catchment as shown in Konz et al. (2006). In the following we describe pre-processing methods to prepare continuous time series of precipitation and temperature data as point information at the meteorological station. The methods are discussed in Sect. 7.1. These time series are the input data for the model. Regionalization of these data is realized in the model itself and therefore discussed in Sect. 4.1.

Air temperature: The filling of missing temperature data $\left(T_{\mathrm{SGHU}}\right)$ is carried out using a second order polynomial function (Weber 1997), which depends only on temperature 


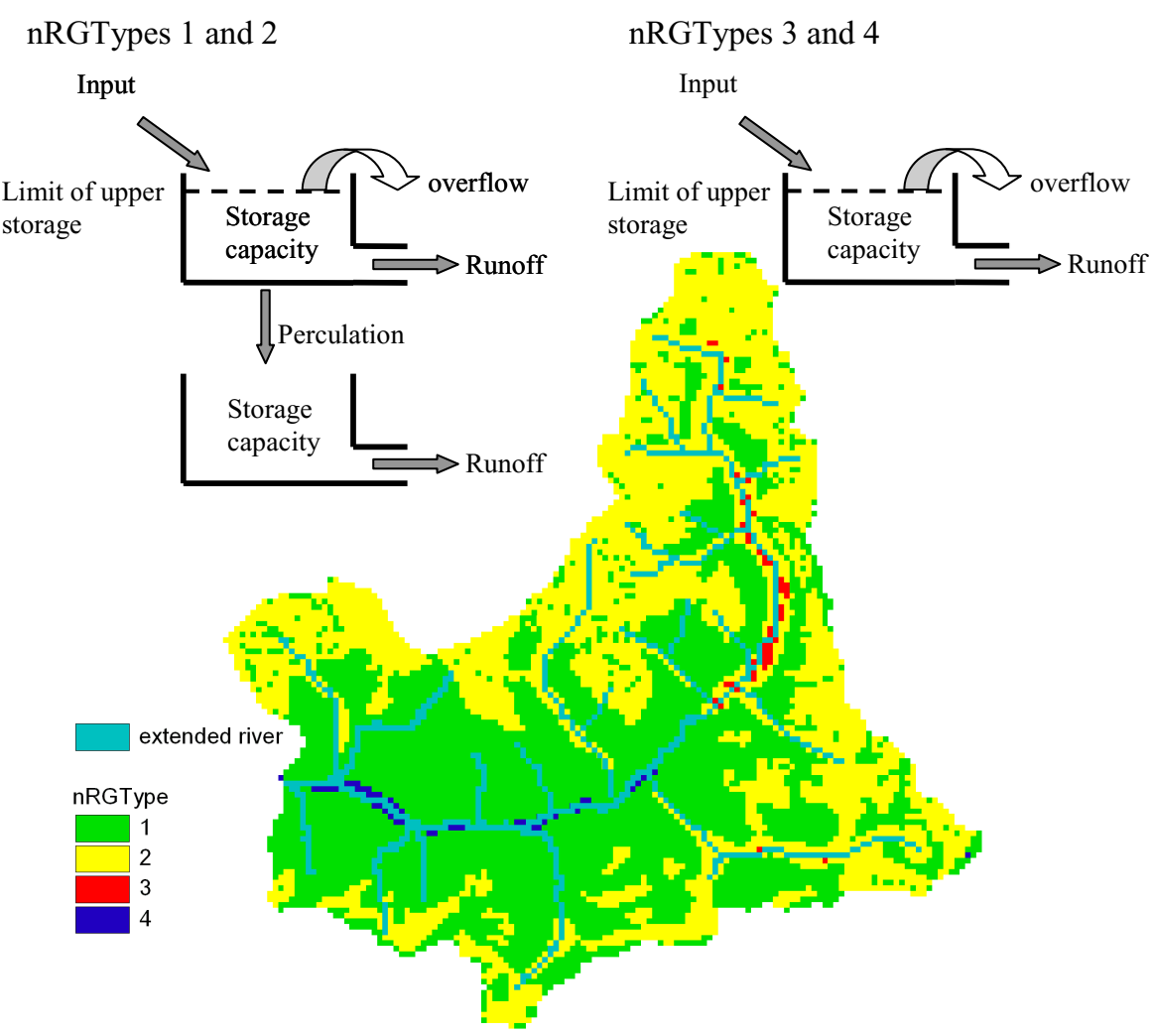

Fig. 2. Conceptualization of reservoirs of the different units of runoff generation types with extended river network.

values of the reference stations $\left(T_{\mathrm{Ref}}\right)$ :

$T_{\mathrm{Ref}}=A T_{\mathrm{SGHU}}^{2}+B T_{\mathrm{SGHU}}+C$

The parameters $(\mathrm{A}, \mathrm{B}, \mathrm{C})$ of the equation are regressively determined from mean monthly air temperature values of the reference station and the SGHU station in the catchment. Only those months were considered where no or minimal (less than three values) data gaps occurred. Although the coefficients were determined for each year individually it can be stated that the parameters only vary slightly from year to year. Therefore, average parameters calculated for years with adequate data availability can be used for years with a large number of missing data. Data quality and availability of the reference station is highly important, thus we used the Katmandu airport station as reference station.

Precipitation: Low lying reference stations (Table 2) are used for filling the missing data. These are the only stations in the region which provide daily precipitation data. The procedure of filling the missing data and redistributing the cumulated values is based on a statistical method, developed by Weber (1997; quoted in Braun et al., 1998). Precipitation data of SGHU station and the reference stations were analyzed according to the following criteria:

1. the occurrence probability of precipitation events for each station and for each month;
2. the joint probability of precipitation occurrence at the SGHU station and the DHM reference stations;

3. the mean ratio of monthly sums of precipitation at the SGHU station and the DHM reference stations, and

4. the "true" monthly sums of precipitation at the SGHU station.

These information are incorporated in a weighting function (Eq. 2) containing the mean ratio of amount of precipitation between reference station $n$ and SGHU station of the month $m\left(F_{n, m}\right)$ and the weighting of reference station $n$ according to the probability of joint occurrence of precipitation at the target station and reference station for the month $m\left(W_{n, m}\right)$. The last step (iv, in the listing above) often involves estimations if missing data occur. The value is used to match the simulated daily precipitation value to a more realistic value.

$P_{\mathrm{SGHU}}=\frac{1}{N} \cdot \sum_{n=1}^{N}\left(P_{n} \cdot F_{n, m} \cdot W_{n, m}\right)$

$P_{\mathrm{SGHU}}$ : extrapolated precipitation at SGHU station $\left(\mathrm{mm} \mathrm{d}^{-1}\right)$

$P_{n}$ : precipitation at reference station $\left(\mathrm{mm} \mathrm{d}^{-1}\right)$

$N$ : Number of reference stations (-) 
Other spatial information: Topographic information was derived from digital maps of the Survey Department of Nepal and of the topographical map of the Deutscher Alpenverein (DAV) (Alpenvereinskartographie, 1990). We developed a digital terrain model (DTM) in a resolution of $200 \times 200 \mathrm{~m}^{2}$ with the help of a Triangular Irregular Network (TIN) based on the digital contour maps of the Survey Department. The vector maps of physiographic features like glacier area, debris covered area or non-glacier covered area were converted into raster maps of the same resolution as the DTM. Glacier covered area was taken from maps published in the glacier inventory of the International Center of Integrated Mountain Development (ICIMOD), Katmandu, Nepal (UNEP/ICIMOD, 2002). The provided digital river network covers the glacier free part of the catchment. However, it has to be assumed that a sub-glacial channel network exists. Field visits have substantiated this assumption. Therefore, the river network was manually extended below glaciers (Fig. 2). This caused a significant improvement of the simulation of the dynamics of the hydrograph.

\subsection{Hydrological and glaciological data for model calibra-} tion and validation

Tracer dilution methods are used to measure discharge as described by Spreafico and Grabs (1993). SGHU continuously performs these measurements several times per year during the dry and rainy seasons. Daily mean discharge $(Q)$ is derived from water level readings $(8 \mathrm{~h})$ and stage-discharge relations. The following Eq. (3) was found to be most suitable for calculation of discharge values $\left(R^{2}=0.92\right)$.

$Q=8.409(h-0.078)^{1.334}$

Glacier mass balances were observed from 19/5/1996 to 6/10/1996 by Fujita et al. (1998) in altitudes from $5150 \mathrm{~m}$ a.s.l. to $5390 \mathrm{~m}$ a.s.l. (Table 3) on debris-free Yala glacier (Fig. 1) in the Langtang Khola catchment. Braun et al. (1993) published mass balances for the period 28/03/1991 to $17 / 03 / 1992$ of the same glacier.

\section{The modeling approach}

The modeling approach is based on the model $\mathrm{TAC}^{\mathrm{D}}$ (tracer aided catchment model, distributed), which is a processbased catchment model with a modular structure. It can be seen as a modified, fully distributed version of the well-know HBV-model with a more process-based runoff generation routine, that uses a spatial delineation of units with the same dominating runoff generation processes. A detailed model description is given by Uhlenbrook et al. (2004) or Uhlenbrook and Sieber (2005). In this study $200 \times 200 \mathrm{~m}^{2}$ grid cells and daily time steps were used. The model routes the water laterally by applying the single-flow direction algorithm (O'Callaghan and Mark, 1984). The model is coded within
Table 3. Glacier mass balances in the Langtang Khola catchment during March 1991-March 1992 (Braun et al., 1993) and MayOctober 1996 (Fujita et al., 1998).

\begin{tabular}{crc}
\hline $\begin{array}{c}\text { Altitude of point } \\
\text { measurement } \\
(\mathrm{m} \text { a.s.1. })\end{array}$ & $\begin{array}{r}\text { Mass } \\
\text { balance } \\
(\mathrm{mm})\end{array}$ & Observation period \\
\hline 5240 & -2240 & March 1991-March 1992 \\
5580 & 510 & March 1991-March 1992 \\
5150 & -2300 & May-October 1996 \\
5190 & -2100 & May-October 1996 \\
5230 & -1700 & May-October 1996 \\
5280 & -1500 & May-October 1996 \\
5350 & -300 & May-October 1996 \\
5380 & 300 & May-October 1996 \\
5390 & 900 & May-October 1996 \\
Areal average & -357 & May-October 1996 \\
\hline
\end{tabular}

the geographical information system PC-Raster (Karssenberg et al., 2001), which offers a dynamic modeling language. Since the highly sophisticated original TAC ${ }^{\mathrm{D}}$ model cannot be applied to catchments with only temperature and precipitation data, substantial modifications of the model were necessary. The model was further simplified and ideas of the HBV-ETH model presented in Braun et al. (1993) were implemented. However, major differences in the spatial discretization and in the simulation of the runoff generation processes remain in comparison to the HBV-ETH model. The glacier module with a distributed snow and ice melt calculation was newly introduced into the model.

\subsection{Regionalization of meteorological input data}

Regionalization of the pre-processed input data is done in the model and is based on vertical and horizontal gradients taken from the literature (Sakai et al., 2004; Shiraiwa et al., 1992). According to Shiraiwa et al. (1992) precipitation decreases from the west to the upper parts of the valley in the north-east due to a mountain barrier running west-east at the southern side of the valley, which causes rain shadowing effects in the northern part. This is considered in the model using a horizontal precipitation gradient of $-3.0 \% 1000 \mathrm{~m}^{-1}$ calculated from the data published by Shiraiwa et al. (1992). In order to compensate for systematic errors in data collection and the lack of representativity of the climatic station, an empirical precipitation correction factor $P C F(-)$ for rain was introduced. Air temperature is distributed with elevation by applying a fixed lapse rate as given by Sakai et al. (2004)

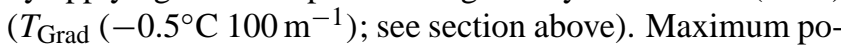
tential evapotranspiration is defined by the parameter $E T_{\max }$ $\left(\mathrm{mm} \mathrm{d}^{-1}\right)$ peaking on 1 August. $E T_{\max }$ is the amplitude of a sinusoidal function with a minimum of $0 \mathrm{~mm} \mathrm{~d}^{-1}$ on 1 February, thus the seasonal variations of the evapotranspiration 
could be simulated. Potential evapotranspiration is regionalized using a fixed, vertical lapse rate of $-1.0 \% 100 \mathrm{~m}^{-1}$ (Sakai et al., 2004).

\subsection{Snow and glacier routine}

The state of precipitation (liquid or solid) is determined based on a temperature threshold $T T\left({ }^{\circ} \mathrm{C}\right)$, such that at each grid cell the precipitation is modeled as snow if the air temperature is below $T T$ and as rain if the air temperature is above TT. A snowfall correction factor $S F C F(-)$, analogue to $P C F$, is introduced that accounts for systematic measurement errors during snowfall. Glaciers are considered as infinite water storages. To simulate snow and ice melt we use the well-known temperature-index method (Zingg, 1951; Braun et al., 1993; Hock, 2003) in a distributed way as shown in Eq. (4).

$$
Q_{\text {melt }}=C F M A X \times\left(T_{\mathrm{SGHU}}-T T\right) R_{\text {expMap }} R_{\text {ice }} R_{\text {debris }}
$$

$Q_{\text {melt }}$ : Melt water $\left(\mathrm{mm} \mathrm{d}^{1}\right)$

CFMAX: Degree-day factor $\left(\mathrm{mm} \mathrm{d}^{-1}{ }^{\circ} \mathrm{C}^{-1}\right)$

$T_{\mathrm{SGHU}}$ : Daily mean air temperature $\left({ }^{\circ} \mathrm{C}\right)$

$T T$ : Threshold value of temperature $\left({ }^{\circ} \mathrm{C}\right)$

$R_{\text {expMap}}$ : Temporal and spatial variable multiplicative factor $(-)$

$R_{\text {debris}}$ : Parameter for reduced melt water production under debris cover (-)

$R_{\text {ice }}$ : Parameter for accelerated melt of ice compared to snow (-)

Emphasis is placed on modeling the temporal, spatial distribution of melt water production as a function of sunshine duration of a day per grid cell. Consequently, the degreeday factor is temporally and spatially distributed according to sunshine duration. This conceptual solution of adapting Hock's idea (Hock, 1999) allows us to simulate melt in a distributed way without the need of additional observations.

Potential sunshine duration is calculated using the model POTRAD (Dam, 2000). This model calculates the potential sunshine duration on each grid cell for the given time step of one day, taking topography (slope, aspect, and shadowing effects) and solar geometry (declination of the sun, latitude, and azimuth angle). A linear relation is used for the transformation of potential sunshine duration into the multiplicative factor for the temperature-index method $R_{\text {expMap }}(-)$ (Eq. 5).

$$
\begin{aligned}
R_{\text {expMap }} & =\left(\left(R_{\exp }-\left(1 / R_{\text {exp }}\right)\right) /\left(\text { Shade }_{\max }-\text { Shade }_{\min }\right)\right) \\
& \times\left(\text { Shade }- \text { Shade }_{\min }\right)+\left(1 / R_{\exp }\right)
\end{aligned}
$$

$R_{\text {exp }}$ : Factor for cells with maximum potential sunshine duration (-)

Shade $_{\max }$ : Maximum potential sunshine duration (h/day): here $13 \mathrm{~h}$

Shade $_{\min }$ : Minimum potential sunshine duration (h/day): here $0 \mathrm{~h}$

Shade: Map stack of potential sunshine durations (h/day)
The calibration parameter $R_{\exp }(-)$ is used to define the range of the temporal and spatial variable $R_{\text {expMap }}$ which is calculated for each day and each grid cell.

Following Braun et al. (1993) the dimensionless parameter $R_{\text {ice }}(>1,-)$ is introduced to the temperature-index method for the simulation of ice melt of the snow-free parts of glaciers. Melt conditions of ice under debris-cover must be considered separately from the conditions of debris-free glaciers. Depending on the thickness of the debris cover, melting can be decoupled from the current meteorological situation. Rana et al. (1996) reported an average thickness of debris cover of $0.5-1.0 \mathrm{~m}$ for the ablation area of Lirung glacier and Langtang glacier (Fig. 1) and therefore a reduction of melt is assumed (see Popovnin and Rozova, 2002). The additional parameter $R_{\text {debris }}(<1,-0)$ in Eq. (4) was introduced following Braun et al. (1993). $R_{\text {debris }}$ and $R_{\text {ice }}$ are set 1.0 if snow melt is calculated or melt of debris-free glaciers is simulated ( $\left.R_{\text {debris }}=1.0, R_{\text {ice }}>1.0\right)$. Melting of firn ("old snow" stored in the snowpack) is calculated the same way as melting of the seasonal snowpack. The model does not account for the movement of ice.

For each cell with a glacier cover, the mass balance is calculated based on the simulated snow accumulation and the simulated snow melt and ice melt. The annual mass balance of the entire glacier is the arithmetic mean of the mass balances of all cells belonging to the same glacier.

\subsection{Soil routine}

Typical soils with clearly identifiable horizons are rare in the catchment, thus, the main function of the soil routine is to store near-surface water and allow evaporation before water reaches the runoff generation routine. The output of the snow routine is the input into the soil routine, which was adopted from the HBV model (Bergström, 1976, 1992). This routine was not changed compared to previous application of $\mathrm{TAC}^{\mathrm{D}}$.

\subsection{Runoff generation routine and runoff routing}

The runoff generation routine is the core of the model. Its structure has to be modified for each catchment, depending on process knowledge and data availability (Uhlenbrook et al., 2004). The routine uses as patial delineation of units with the same dominating runoff generation processes. Usually, the units have to be delineated with supporting information on runoff sources or flow paths. These insights into catchment characteristics are gained from tracer experiments and hydrochemical data. In the case of Himalayan catchments these data are not available. However, as shown in Braun et al. (1993), a simpler lumped runoff generation routine is not able to simulate discharge without statistical corrections. With the distributed approach we can implement distinct conceptualised runoff generation processes of obviously different units. Since tracer data are missing only basic units can 
be distinguished based on topography and physiographic information.

Units with similar dominating runoff generation behavior were delineated using maps of topography and land use, aerial photographs and a DEM as well as experiences gained during field visits. The delineation is the basis for translating the dominating runoff generation processes into the runoff generation routine of the model, as it defines the model structure and parameterization. The way the delineation was carried was fed also by extensive experiences obtained in hydro-glaciological research projects at European and tropical glaciers in the last decades. The plausibility of the spatial delineation of units was discussed with local experts supported by field observations during different seasons. Four units were distinguished (Fig. 2):

1. non-glacier area (nRGType 1,53\% of catchment area),

2. glacier area (nRGType $2,45 \%)$,

3. glacier area with an inclination of less than $3^{\circ}$ and debris cover (nRGType 3, 1\%), and,

4. valley bottoms with an inclination of less than $8^{\circ}$ (nRGType 4, 1\%).

Sequentially connected or overflowing reservoirs simulate the runoff processes of unit types 1 and 2. In these units upper and lower storages exist which are vertically linked via a constant percolation rate. For conceptualization of the runoff generation processes of the third unit type (nRGType 3 ), only a single storage is used. Storage capacity is limited by an upper limit. Runoff of this storage is computed by applying a storage coefficient with additional water if the storage content exceeds the storage capacity. This conceptualization is based on the assumption that the large valley glaciers can store a great amount of water in pools or small sub- and supra-glacial lakes (Jansson et al., 2002). Thus, the upper limit of the storage capacity is larger than the upper limits of the storages of unit types 1,2 or 4 .

A fourth unit (nRGType 4) was identified based on information acquired during field visits and on aerial photographs. At the valley bottom with an inclination of less than $8^{\circ}$ it is considered to exist an aquifer made of glacial moraine and gravel beds where water can be stored. The same structure of storage as in nRGType 3 is used to simulate the hydrological processes but with different parameterization for different flow dynamics.

Once water fluxes have reached stream cells, the generated runoff is routed to the outlet of the catchment during the same time step. Since the time step is one day this can be justified in alpine environments where river flows are turbulent and fast.

\section{Model application}

The model was tested in the validation period 1987-1993 with the best parameter set obtained in the calibration period 1993-1997 by manual trial and error technique. The later period was chosen for model calibration because the quality of meteorological data is better during this period. In addition to the visual inspection of the simulated hydrographs four different objective evaluation criteria were used: The model efficiency $R_{\text {eff }}$ (Nash and Sutcliffe, 1970), the model efficiency using logarithmic discharge values $\log R_{\text {eff }}$, the coefficient of determination $R^{2}$, and the volume error $V E$, which is the accumulated difference between simulated and measured discharge of a defined period. The $\log R_{\text {eff }}$ is particularly useful to evaluate low flows as it emphasizes on low discharges.

The initial model parameter set was estimated according to basin characteristics, available data from literature (e.g. snow routine) or was derived based on experiences from previous $\mathrm{TAC}^{\mathrm{D}}$-applications to other basins. In particular, the parameter values of the soil routine and runoff generation routine were defined such that our understanding of the dominant process behavior is represented. Thus, for instance the outflow parameters of the reservoirs of the runoff generation routine (cf. Fig. 2) were estimated that the simulated runoff dynamics agree with our process knowledge. To get reasonable initial storage volumes the years before the calibration period were modeled using meteorological data of the validation period. Calibration runs were performed by adjusting only parameters of the snow and glacier routine and the precipitation input parameters $S F C F$ and $P C F$. The initial parameters of the soil routine and the runoff generation routine were not further adjusted as they were defined to represent our process understanding.

Glaciers are sources of runoff water, but their contribution is hard to estimate from discharge and scarce meteorological data alone. An overestimation of melt water production can, for instance, compensate for underestimated basin precipitation, or vice versa. Therefore, good simulation results can occur for the wrong reasons. In order to improve the simulations, data about the glacier mass balances in addition to discharge were considered in the calibration procedure to find the best parameter set (Table 4) of the snow and glacier routine. A parameter fine-tuning or investigations of the model uncertainties (equifinality problem, GLUE or other methodolgies) were beyond the scope of this study. It is worth noting in this respect that the simulation of e.g. the calibration period (5 years) took about 30 min (desktop PC, CPU 1.6 Ghz), because of the integration of the model into the GIS which made the model simulation slow.

\section{Simulation results}

The model results show that about $47 \%$ of the basin precipitation falls as snow and 53\% as rain, even though $74 \%$ 
Table 4. Optimized parameter set of $\mathrm{TAC}^{\mathrm{D}}$ for the Langtang Khola catchment.

\begin{tabular}{|c|c|c|c|c|}
\hline Parameter & Description & Determination & Value & Unit \\
\hline \multicolumn{5}{|c|}{ Precipitation correction and regionalization } \\
\hline$P C F$ & Precipitation correction factor for rain & Calibration & 1.05 & $(-)$ \\
\hline$P_{\text {Grad }}$ & Vertical precipitation gradient & Calibration (Externally defined, based on literature) & 0.04 & $\left(\% 100 \mathrm{~m}^{-1} 100^{-1}\right)$ \\
\hline$P_{\text {HorizGrad }}$ & Horizontal precipitation gradient & Calibration (Externally defined, based on literature) & -0.03 & $\left(\% 1000 \mathrm{~m}^{-1} 100^{-1}\right)$ \\
\hline$S F C F$ & Snowfall correction factor & Calibration & 1.2 & $(-)$ \\
\hline \multicolumn{5}{|c|}{ Temperature regionalization } \\
\hline$T_{\text {Grad }}$ & Vertical temperature gradient & Calibration (Externally defined, based on literature) & -0.5 & $\left({ }^{\circ} \mathrm{C} 100 \mathrm{~m}^{-1}\right)$ \\
\hline \multicolumn{5}{|c|}{ Potential evaporation calculation and regionalization } \\
\hline$E T_{\max }$ & Maximum of potential evapotranspiration & Calibration (Externally defined, based on literature) & 2.2 & $\left(\mathrm{~mm} \mathrm{~d}^{-1}\right)$ \\
\hline$E T_{\mathrm{Grad}}$ & Vertical evapotranspiration gradient & Calibration (Externally defined, based on literature) & -0.01 & $\left(\% 100 \mathrm{~m}^{-1} 100^{-1}\right)$ \\
\hline \multicolumn{5}{|c|}{ Snow and glacier routine } \\
\hline$T T$ & $\begin{array}{l}\text { Threshold value of temperature for snowfall also gen- } \\
\text { eral temperature correction }\end{array}$ & Calibration (Externally defined, based on literature) & -0.2 & $\left({ }^{\circ} \mathrm{C}\right)$ \\
\hline CFMAX & Degree-day factor & Calibration & 7.0 & $\left(\mathrm{~mm}^{\circ} \mathrm{C}^{-1} \mathrm{~d}^{-1}\right)$ \\
\hline $\mathrm{CWH}$ & Water holding capacity of snow & Literature (Bergström, 1992) & 0.1 & $(-)$ \\
\hline CFR & Coefficient of refreezing & Literature (Bergström, 1992) & 0.05 & $(-)$ \\
\hline$R_{\exp }$ & $\begin{array}{l}\text { Multiplicative factor for cells with maximum potential } \\
\text { sunshine duration }\end{array}$ & Calibration & 1.3 & $(-)$ \\
\hline$R_{\text {ice }}$ & $\begin{array}{l}\text { Multiplicative factor to account for accelerated melt } \\
\text { over ice as compared to snow }\end{array}$ & Calibration & 1.4 & $(-)$ \\
\hline$R_{\text {debris }}$ & $\begin{array}{l}\text { Reduction factor of glaciermelt over debris-covered } \\
\text { parts of the glacier }\end{array}$ & Calibration (Externally defined, based on literature) & 0.3 & $(-)$ \\
\hline \multicolumn{5}{|c|}{ Soil routine } \\
\hline LP & Reduction parameter of field capacity & Literature (Menzel 1997) & 0.6 & $(-)$ \\
\hline \multicolumn{5}{|c|}{ Non-glacier area (nRGType 1) } \\
\hline $\mathrm{FC} 1$ & Maximum soil moisture storage (field capacity) & Calibration & 20 & $(\mathrm{~mm})$ \\
\hline BETA1 & Empirical parameter & Calibration & 2.0 & $(-)$ \\
\hline \multicolumn{5}{|c|}{ Glacier area (nRGType 2) } \\
\hline $\mathrm{FC} 2$ & Maximum soil moisture storage (field capacity) & Calibration & 20 & $(\mathrm{~mm})$ \\
\hline BETA2 & Empirical parameter & Calibration & 1.5 & $(-)$ \\
\hline \multicolumn{5}{|c|}{ Glacier area with inclination less $3^{\circ}$ and debris cover (nRGType 3 ) } \\
\hline FC3 & Maximum soil moisture storage (field capacity) & Calibration & 40 & $(\mathrm{~mm})$ \\
\hline BETA3 & Empirical parameter & Calibration & 1.5 & $(-)$ \\
\hline \multicolumn{5}{|c|}{ Valley bottom with inclination less $8^{\circ}$ (nRGType 4 ) } \\
\hline FC4 & Maximum soil moisture storage (field capacity) & Calibration & 120 & $(\mathrm{~mm})$ \\
\hline BETA4 & Empirical parameter & Calibration & 2.5 & $(-)$ \\
\hline \multicolumn{5}{|c|}{$\begin{array}{l}\text { Runoff generation routine } \\
\text { Non-glacier area (nRGType 1) }\end{array}$} \\
\hline US_K1 & Storage coefficient of upper storage & Calibration & 0.13 & $\left(d^{-1}\right)$ \\
\hline LS_K1 & Storage coefficient of lower storage & Calibration & 0.005 & $\left(d^{-1}\right)$ \\
\hline US_P1 & Percolation capacity & Calibration & 1 & $\left(\mathrm{~mm} \mathrm{~d}^{-1}\right)$ \\
\hline US_H1 & Limit of upper storage & Calibration & 100 & $(\mathrm{~mm})$ \\
\hline \multicolumn{5}{|c|}{ Glacier area (nRGType 2) } \\
\hline US_K2 & Storage coefficient of upper storage & Calibration & 0.1 & $\left(d^{-1}\right)$ \\
\hline LS_K2 & Storage coefficient of lower storage & Calibration & 0.02 & $\left(d^{-1}\right)$ \\
\hline US_P2 & Percolation capacity & Calibration & 3 & $\left(\mathrm{~mm} \mathrm{~d}^{-1}\right)$ \\
\hline US_H2 & Limit of upper storage & Calibration & 200 & $(\mathrm{~mm})$ \\
\hline \multicolumn{5}{|c|}{ Glacier area with inclination less $3^{\circ}$ and debris cover (nRGType 3 ) } \\
\hline GlacierLS_K & Storage coefficient of glacier storage & Calibration & 0.01 & $\left(d^{-1}\right)$ \\
\hline GlacierLS_H & Limit of glacier storage & Calibration & 3000 & $(\mathrm{~mm})$ \\
\hline \multicolumn{5}{|c|}{ Valley bottom with inclination less $8^{\circ}$ (nRGType 4) } \\
\hline ValleyLS_K & Storage coefficient of valley storage & Calibration & 0.01 & $\left(d^{-1}\right)$ \\
\hline ValleyLS_H & Limit of valley storage & Calibration & 1000 & $(\mathrm{~mm})$ \\
\hline \multicolumn{5}{|c|}{ Routing routine } \\
\hline MaxBas & Empirical parameter & Set a priori & 1 & $(-)$ \\
\hline
\end{tabular}


Table 5. Comparison of evaluation criteria of simulations with $\mathrm{TAC}^{\mathrm{D}}$ and HBV-ETH. Calibration period,1993-1997, and validation period, 1987-1993.

\begin{tabular}{ccccccccc}
\hline \multicolumn{9}{c}{ TAC $^{\mathrm{D}}$} \\
\hline & $R_{\text {eff }}(-)$ & $\log R_{\text {eff }}(-)$ & $R^{2}(-)$ & $V E(\mathrm{~mm} / \mathrm{a})$ & $R_{\text {eff }}(-)$ & $\log R_{\text {eff }}(-)$ & $R^{2}(-)$ & $V E(\mathrm{~mm} / \mathrm{a})$ \\
\hline $1987 / 88$ & 0.58 & 0.05 & 0.87 & 97 & 0.26 & -2.83 & 0.78 & 258 \\
$1988 / 89$ & 0.72 & 0.32 & 0.90 & 40 & 0.37 & -1.45 & 0.81 & 161 \\
$1989 / 90$ & 0.68 & 0.45 & 0.84 & 50 & 0.37 & -0.49 & 0.77 & 20 \\
$1990 / 91$ & 0.20 & 0.40 & 0.88 & -30 & -0.33 & -0.38 & 0.80 & -136 \\
$1991 / 92$ & 0.30 & 0.59 & 0.82 & -9 & -0.05 & -0.44 & 0.68 & 80 \\
$1992 / 93$ & 0.76 & 0.68 & 0.91 & 37 & 0.40 & -0.60 & 0.76 & 107 \\
$1993 / 94$ & 0.85 & 0.75 & 0.89 & 57 & 0.59 & 0.07 & 0.75 & 123 \\
$1994 / 95$ & 0.87 & 0.80 & 0.88 & -8 & 0.83 & 0.63 & 0.91 & 126 \\
$1995 / 96$ & 0.53 & 0.31 & 0.72 & 92 & 0.29 & -0.38 & 0.62 & 81 \\
$1996 / 97$ & 0.46 & 0.84 & 0.76 & -8 & 0.18 & 0.15 & 0.63 & 46 \\
\hline
\end{tabular}

of precipitation fall in the relatively warm monsoon period. This demonstrates the important role of snow and ice storage and melt for the water balance in this basin with a glacierization of about $46 \%$. Basin precipitation ( 432 to $668 \mathrm{~mm} / \mathrm{a}$ ) and discharge ( 470 to $694 \mathrm{~mm} / \mathrm{a}$ ) are by far the largest components, followed by glacier melt ( 274 to $422 \mathrm{~mm} / \mathrm{a}$ ). The change in storage (135 to $279 \mathrm{~mm} / \mathrm{a}$ ) summarizes water storage in groundwater, snow pack or ice and soil. Actual evapotranspiration accounts for 12 to $17 \%$ of the input precipitation. The first two hydrological years of the calibration period show a good agreement of the simulated and measured discharge (Table 5). The dynamics of the hydrograph are reproduced satisfactorily using the modified TAC ${ }^{\mathrm{D}}$. From the hydrological year 1995/96 onwards the model overestimates discharge. Figure 3 shows comparisons of simulated and measured discharge data.

The winter discharge is simulated well in the years 1993/94, 1994/95 and 1996/97 with logarithmic model efficiencies ( $\log R_{\text {eff }}$ ) from 0.75 to 0.84 (Table 5). However, the simulated onset of discharge in May and June is delayed in most of the years by some 10 days and, consequently, discharge is underestimated at the beginning of the melt/monsoon period. Additionally, discharge is generally overestimated in the second half of the melt/monsoon period.

The glacier mass balances are calculated for the cells in which the point measurements took place. Figure 4 shows that the balances generally are underestimated both in the ablation area and in the accumulation area.

However, the simulated balances are in the right order of magnitude. Fujita et al. (1998) determined the aerial average mass balance of Yala glacier for the investigation period of about 20 weeks as $-357 \mathrm{~mm}$; the simulated mass balance for entire Yala glacier is $-332 \mathrm{~mm}$ for the same period, which compares favorably considering the accuracy of mass balance measurements.
Measured winter discharge is higher in the validation period, with an average from November to the end of April of $3.35 \mathrm{~m}^{3} / \mathrm{s}$ compared to the average of $2.73 \mathrm{~m}^{3} / \mathrm{s}$ in the calibration period. The modified $\mathrm{TAC}^{\mathrm{D}}$ underestimates winter discharge in all hydrological years of the validation period and tends to overestimate discharge in the melt/monsoon period. These compensating effects are the reason for the relatively small volume errors (Table 5). $R_{\text {eff }}$ and $\log R_{\text {eff }}$, however, show a drop in performance during the validation period compared to the calibration period, whereas the coefficient of determination indicates a strong connection between measured and simulated hydrograph.

The comparison of measured $(-2240 \mathrm{~mm}$ at $5250 \mathrm{~m}$ a.s.l. and $510 \mathrm{~mm}$ at $5560 \mathrm{~m}$ a.s.l., on Yala glacier, Braun et al., 1993) and simulated $(-1872 \mathrm{~mm}$ at $5250 \mathrm{~m}$ a.s.l. and $486 \mathrm{~mm}$ at $5560 \mathrm{~m}$ a.s.l.) mass balances of the validation period is satisfactory and points towards that the parameterization of the snow and glacier routine of the calibration period is representative for the entire simulation period.

\section{Discussion}

\subsection{Pre-processing of input data}

The second order polynomial function used to bridge gaps in temperature time series can reproduce the measured temperature course and even single patterns were modeled realistically. The simulation of the monsoon season is generally better than the simulation of the dry season. The coefficients of determination $\left(R^{2}\right)$ of the years in which the method was applied varied between 0.70 and 0.91 . Note that the simulated values were used only to fill the missing values in the time series.

The measured precipitation values are compared with the simulated values of June and July 1997 in Fig. 4 for the illustration of the precipitation simulation results. Some 

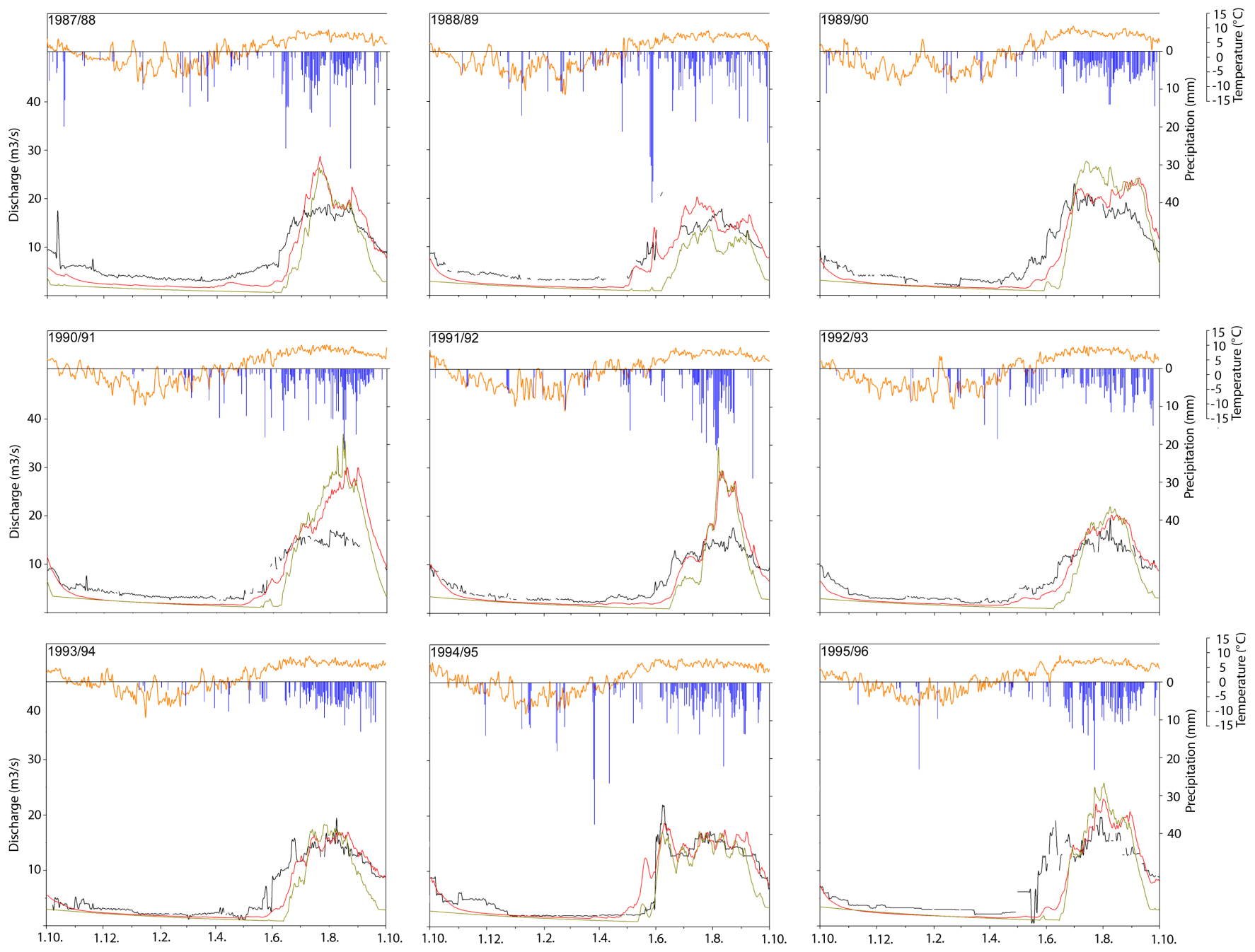

Fig. 3. Simulation results of $\mathrm{TAC}^{\mathrm{D}}$ and HBV-ETH model.

of the precipitation sums are reproduced well, e.g. around 27/7/1997; others are redistributed over several days, e.g. around 29 June 1997. However, there are some significant deviations between the measured and the simulated precipitation values. The reconstruction of the precipitation sums is based on probabilities and it is not an extrapolation like the temperature extrapolation where reliable correlations between SGHU station and reference stations are a prerequisite. Nevertheless, it is concluded that the extrapolated time series are able to describe the actual situation adequately and the main patterns, e.g. timing and magnitude, of the measured precipitation sums are reproduced well by the algorithm. The simulated daily precipitation sums were adjusted to the actual precipitation sums using the ratio of calculated and measured monthly precipitation sums and therefore the deviations of the monthly amounts of precipitation are not significant. If data availability is not sufficient, monthly precipitation sums had to be estimated from other years. The temporal shift of the simulated precipitation sums does not necessarily influence the discharge simulation. If the storage capacities of snow pack or of the storages of the runoff generation routine are not exceeded, additional water is added to these storages and contributes to runoff generation with some retardation. Thus, errors in temporal assignment of simulated daily precipitation values can be tolerated by the model too some extent. It must be further considered that precipitation events in the same region do not always occur at the same time or are stationary throughout the event. If precipitation occurs at a reference station at one day the algorithm implies that there is rain- or snowfall at the SGHU station on the same day, whereas the precipitation event might have occurred in reality on the following day at the SGHU station. This causes temporal inaccuracies of the simulated precipitation sums even if there is a strong connection of the meteorological conditions between the region and the target station (SGHU station).A comparison of the simulated hydrographs 


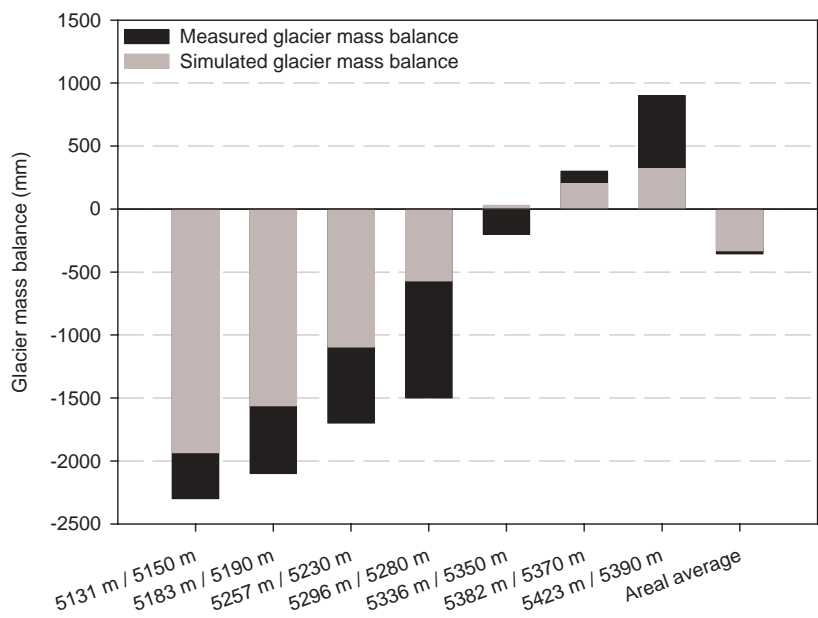

Fig. 4. Comparison of simulated glacier mass balances with the TAC $^{\mathrm{D}}$ model and measured glacier mass balances at different altitudes on Yala glacier from 19/05/1996 to 6/10/1996 (Fig. 1). The black bars are behind the gray bars and both start at $0.00 \mathrm{~mm}$. First numbers of $x$-axis are the altitudes of the $200 \times 200 \mathrm{~m}^{2}$ cells in which the balance was measured. Second numbers show the altitudes of the observation points.

calculated based on measured daily precipitation sums and on the synthetic daily precipitation sums in Fig. 5 shows that the differences are small for most of the times.

The hydrological year 1995/96 was chosen for that comparison because this year shows neither missing values nor accumulated precipitation sums over several days in the original measured time series. Thus, no pre-processing was applied for this year and therefore it is applicable for the evaluation of the precipitation pre-processing method. The measured precipitation event of 25/7/1996 amounts to $25 \mathrm{~mm}$ while the method to fill the missing values distributes this amount over previous days as the measured precipitation sums of the reference stations implies. The discharge peak calculated with the measured precipitation sums is therefore not found in the simulated discharge with synthetic precipitation input. To summarize, the pre-processing methods for temperature and precipitation data are generally appropriate for filling missing values in the time series and for redistributing precipitation sums. They can further be used for reliability assessment of measured data.

\subsection{Regionalization of input data and evapotranspiration}

The regionalization of air temperature and precipitation in the model itself with fixed vertical and horizontal gradients seems more problematic because seasonal variations of the gradients are not considered. As precipitation and air temperature measurements are available for only one station in the catchment the use of sophisticated regionalization methods (e.g. Kriging or Inverse Distance Weighting) for the meteorological input data are prevented. The introduction of the

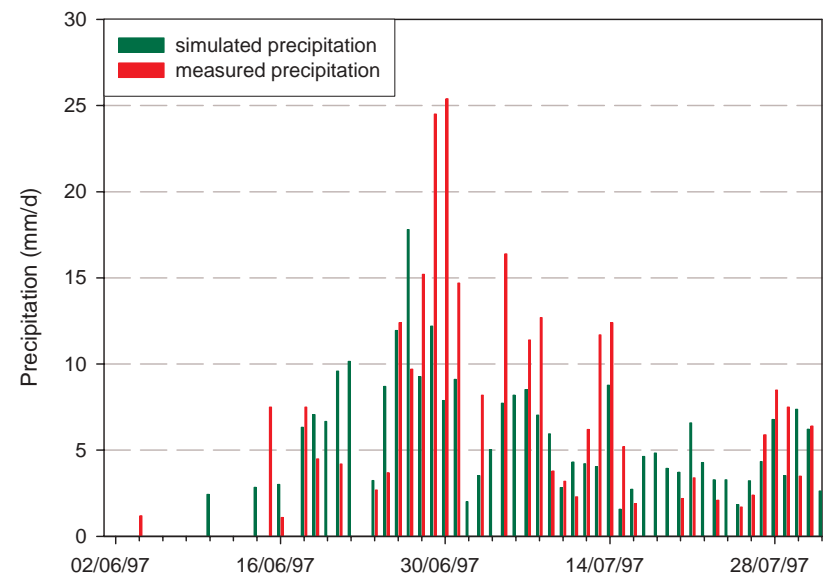

Fig. 5. Comparison of measured daily precipitation sums (red bars) and simulated daily precipitation sums (green bars).

horizontal gradient that is substantiated by the topographic situation (Shiraiwa et al., 1992), however, enables a more realistic distribution of the basin precipitation with less precipitation in the north of the catchment. There is only one station in the Langtang Khola catchment itself (located in the main valley close to the outlet!) which is meant to represent the entire meteorological situation of the catchment. The absence of further data makes the evaluation of the representativity of this station hard and an independent evaluation of the spatial and temporal extrapolation of the precipitation data impossible.

For the calculation of the potential evapotranspiration a simple sinusoidal approach was chosen (Hottelet et al., 1993). Only $14.6 \%$ of the entire catchment area is below $4500 \mathrm{~m}$ and as evaporation generally decreases with elevation and with the presence of snow and ice covers, this term plays a minor role in the water balance (Lang, 1981). Further, no additional data are required to simulate evapotranspiration following this approach.

\subsection{Temporally and spatially distributed modeling of snow and ice melt}

Since there is no basis for a direct evaluation of the distributed melt modeling approach we demonstrate how the algorithm works in general. Figure 7 shows the spatial distribution of $R_{\text {expMap }}$ for the winter and the summer solstice. The spatial distribution of $R_{\text {expMap }}$ shows realistic patterns: on 21 December the lowest values of $R_{\text {expMap }}$ can be found at the north-oriented slopes at the valley bottom, whereas the highest values occur at the peaks and at highly elevated south-oriented plateaus. The zenith angle of the sun is close to $0^{\circ}$ in the Langtang valley at the summer solstice due to its location close to the Tropic of Cancer $\left(23.5^{\circ} \mathrm{N}\right)$. Thus, the map of 21 June shows the highest values at cells with northern and southern orientation and at the peaks or ridges. 


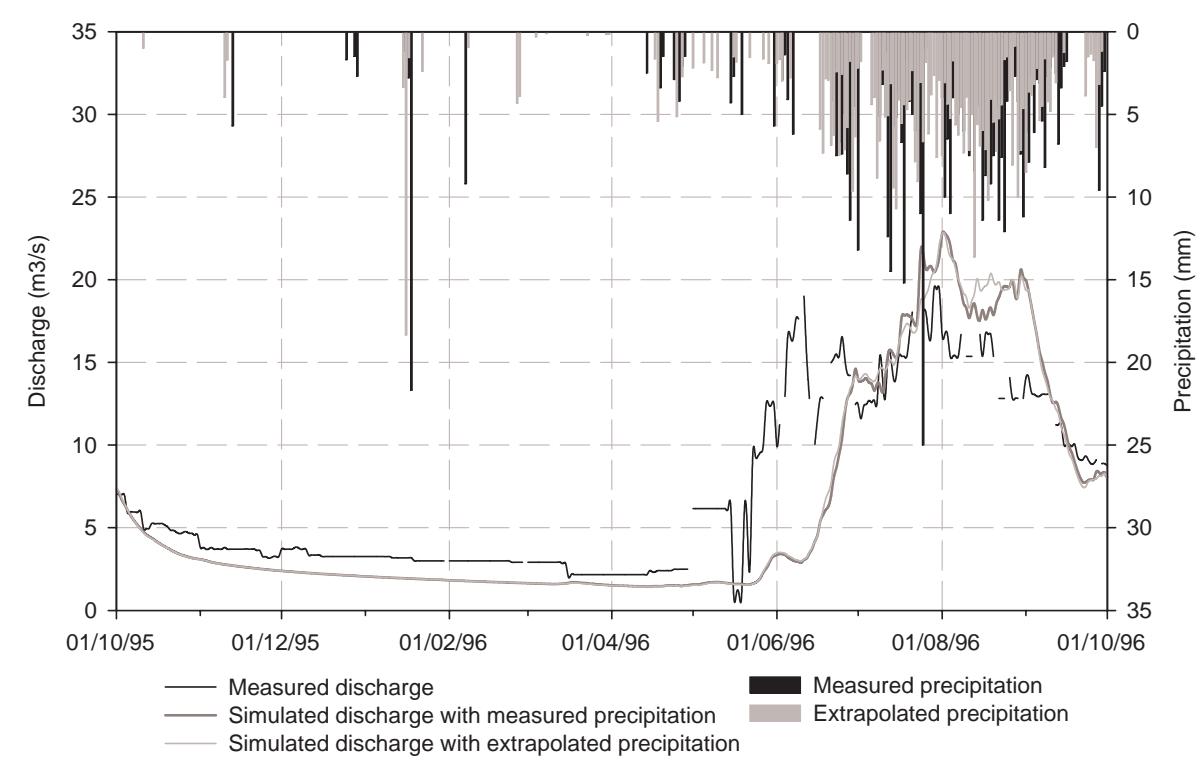

Fig. 6. Comparison of the influences of different precipitation inputs on the discharge simulation. The hydrological year $1995 / 96$ was chosen because of the data availability.
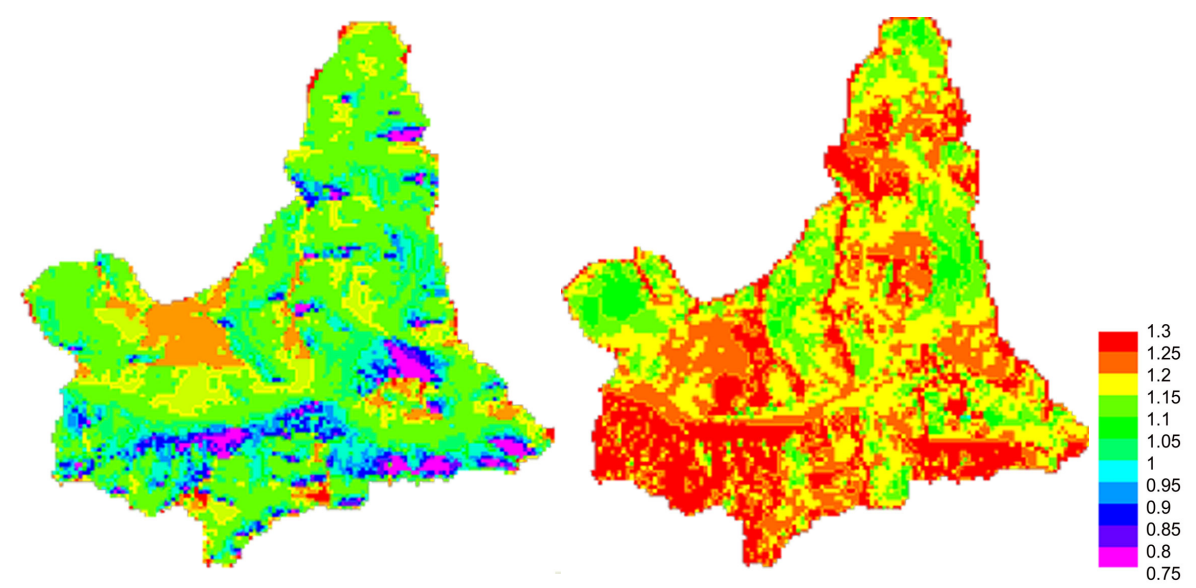

Fig. 7. Spatial distribution of the correction factor for the degree-day method $R_{\text {expMap }}(-)$ at the winter solstice (21 December, left) and the summer solstice (21 June, right).

The lowest values are at east- or west-oriented slopes. To summarize, the introduction of $R_{\text {expMap }}$ enabled spatial and temporal distributed modeling of snow- and ice melt based on topographic and astronomic information.

The estimated degree-day factor (product of CFMAX, $R_{\text {expMap }}, R_{\text {ice }}$ and $R_{\text {debris }}$ ) is about twice as high as in degreeday model applications in catchments in the European Alps (e.g. Braun and Aellen, 1990). Observations of the surface glacier melt rates are reported for the Yala glacier at 5100 m a.s.l. (Fig. 1) by Motoyama and Yamada (1989) for the period 23 August-3 September 1987, and a value of $12.7 \mathrm{~mm}^{\circ} \mathrm{C}^{-1} \mathrm{~d}^{-1}$ (based on hourly values) was observed. Here, our simulated value (debris free glacier, $R_{\text {debris }}=1$ ) for the same area amounts to $11.9 \mathrm{~mm}^{\circ} \mathrm{C}^{-1} \mathrm{~d}^{-1}$ and compares well with the observations. Further literature values of surface glacier melt rates on Khumbu glacier (Mount Everest region) were even larger with $16.9 \mathrm{~mm}^{\circ} \mathrm{C}^{-1} \mathrm{~d}^{-1}$ for bare ice (Kayastha et al., 2000).

About 19\% of the glaciers in the Langtang Khola catchment are covered by debris, most of which lie in the lowest parts of the basin. The parameter $R_{\text {multd }}$ was introduced to account for the reduction of ice melt beneath the debris layer. The sensitivity analysis (Fig. 7) of this parameter shows that discharge is generally underestimated if melt is suppressed totally $\left(R_{\text {multd }}=0.0\right)$ and overestimated if debriscovered glaciers are treated the same way as clean glaciers $\left(R_{\text {multd }}=1.0\right)$. 
In the sample year 1994/95 volume losses of $100 \mathrm{~mm} / \mathrm{a}$ occur when setting $R_{\text {multd }}=0.0$, discharge is overestimated by about $269 \mathrm{~mm} / \mathrm{a}$ if $R_{\text {multd }}=1.0 . R_{\text {multd }}=0.3$ was chosen based on the experiences of Popovnin et al. (2002) at Djankuat glacier, Caucasus. They found a reduction of melt under debris layers of 50 to $70 \mathrm{~cm}$ of approximately $70 \%$ compared to the melt rate of bare ice.

7.4 Goodness of simulation of discharge and glacier mass balances

The overall performance of the model for the hydrological years 1993/94 and 1994/95 can be considered as good (e.g. Rango, 1992). However, there are various reasons for partly insufficient simulation results (i.e. simulation of onset of monsoon period, simulation of single peaks, and simulation of glacial mass balances) that will be discussed in the following.

First, one reason for the differences of the simulated and measured glacier mass balances is the cell size of $200 \times 200 \mathrm{~m}^{2}$ used in the model. That means that point measurements are compared with simulated mass balances of an area of $40000 \mathrm{~m}^{2}$. The altitudes of the cells and of the point measurements differ, because the altitude of the grid cells is an average value of the $40000 \mathrm{~m}^{2}$ area. Therefore, different meteorological conditions prevail at the cells and at the observation points.

Second, the spatial resolution of $200 \times 200 \mathrm{~m}^{2}$ and the relatively large daily time step causes a damping of the fast runoff components. A reduction of the time step from daily to hourly intervals was not possible because measurements were only available in daily resolution. A coarser spatial resolution would improve the simulation of fast runoff components, because traveling distance is larger per time step. This is, however, problematic for the simulation of snow- and ice melt because detailed physiographic information gets lost with a coarser spatial resolution.

Third, the simulation of the onset of discharge at the beginning of the monsoon period is delayed by some ten days. Redistribution of snow via possible avalanches and wind drift must also have a significant impact on the melting conditions of the early monsoon period. If snow, which has fallen during winter period is redistributed into lower altitudes it will start melting earlier causing higher runoff generation in the beginning of the monsoon season. However, mass movements through avalanches and wind drift could not be considered in the model. In the future, remote sensing data might help to estimate the impact of such processes on the aerial redistribution of snow and, consequently, lead to more realistic input data sets.

The additional glacier mass balance data of the calibration and validation period enabled a more reliable adjustment of the parameter of the snow and glacier routine. Thus, the mass balance data were taken as valuable additional criteria beside discharge data for calibration and validation of the model.

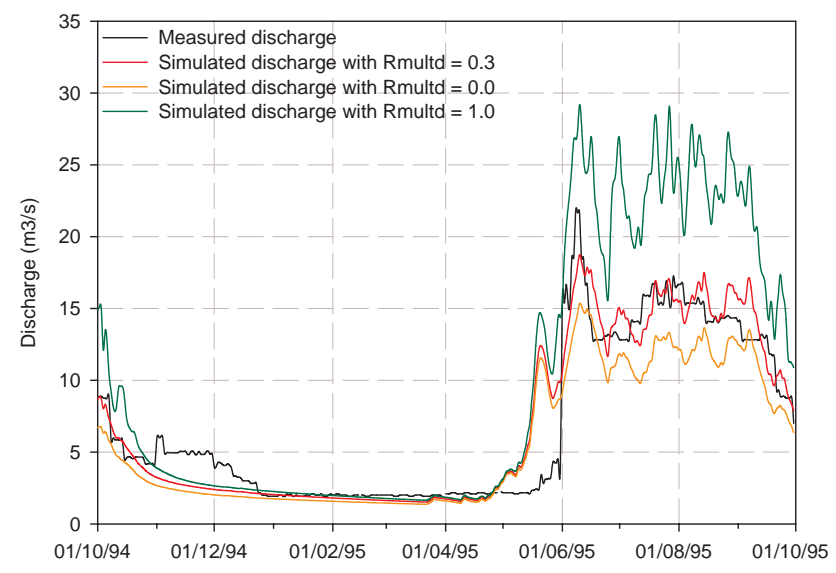

Fig. 8. Sensitivity of the parameter $R_{\text {multd }}$, Langtang Khola catchment.

\subsection{Analysis on dominant runoff components}

The intra-annual distribution of water with the spatially distributed reservoir concepts of the model enabled good simulation results as expressed by the objective evaluation criteria. The composition of runoff shows seasonal variations (Fig. 8).

The high flow season is dominated by the outflow from the upper storages. The low flow is mainly a superposition of runoff of the lower storages of nRGType 1 and 2 and of the storages of nRGTypes 3 and 4. Outflow from the storages of nRGTypes 3 and 4 are important components for the maintenance of winter discharge although the area of these HRUs is small (2\%) compared to the contribution areas of nRGType 1 or 2 . Water coming from units 1 or 2 has to pass units 3 or 4 on its lateral flow and thus fills these storages beside precipitation and snow melt.

A conceptual storage approach that is not too complex but represents the main runoff generation processes of the Langtang Khola catchment can be considered as suitable. With these sequentially linked storages it was possible to simulate water storage in glaciers and the underlying hard rock with different hydraulic behavior. Thus, it was not necessary to apply a synthetic constant value for base flow as in Braun et al. (1993). The topographic information combined with land use and surface characteristics for the delineation of hydrological response units enabled a more realistic runoff generation simulation in the remote study area, where additional information (e.g. tracer experiments) were not available.

\subsection{Comparison of TAC $^{\mathrm{D}}$ with the HBV-ETH model}

The simulation results of $\mathrm{TAC}^{\mathrm{D}}$ are compared with the results of the HBV-ETH model to provide a broader context for assessing TAC ${ }^{\mathrm{D}}$. The HBV-ETH precipitation-runoff model is a version of the widely used HBV model (Bergström, 1976 , 1992) ith special features to calculate the runoff of 


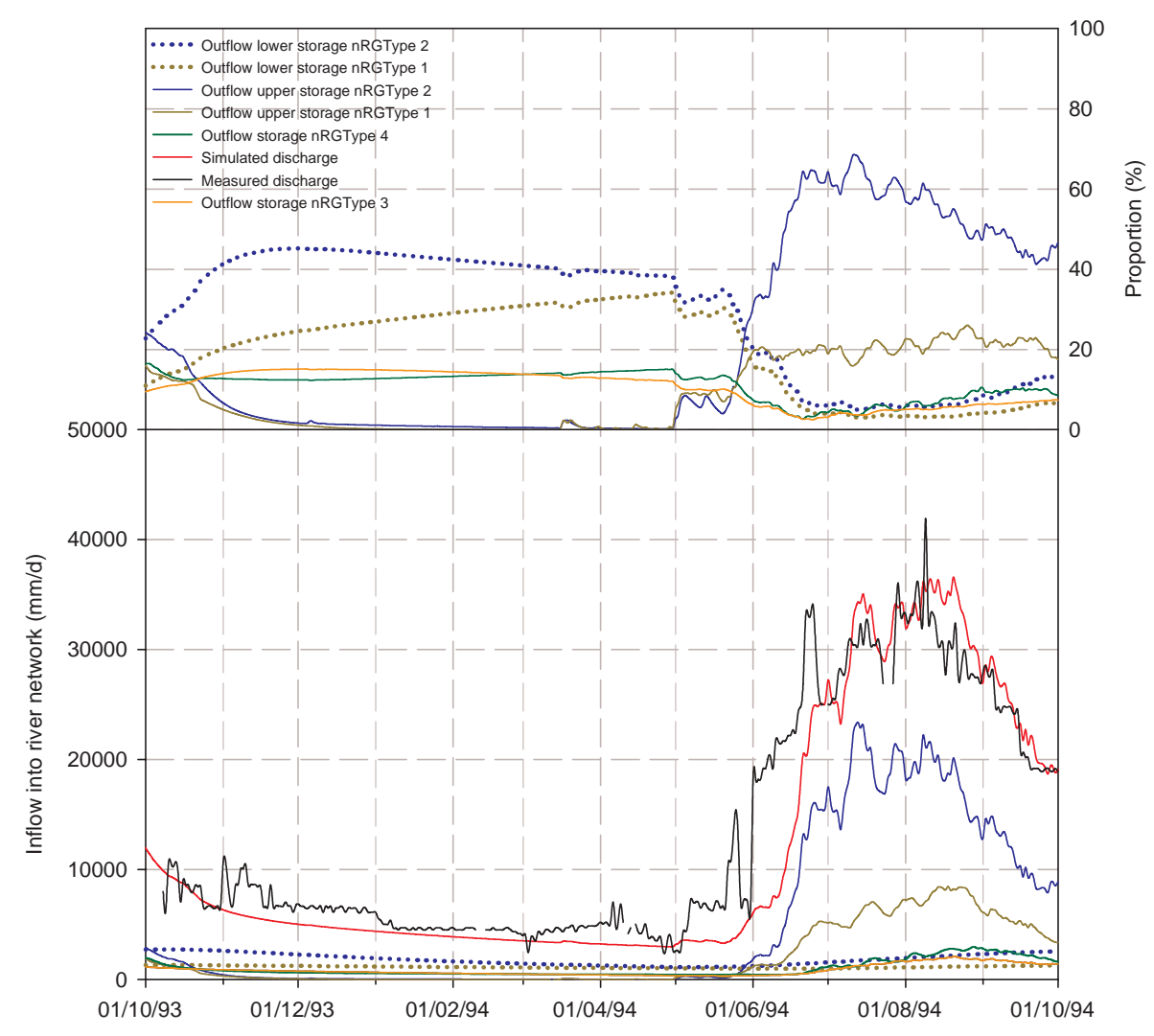

Fig. 9. Contribution of each runoff component to the entire runoff in percent of the entire runoff (upper graphic) and as absolute values (lower graphic) for the hydrological year 1993/94, Langtang Khola catchment.

glacierized catchments (Braun and Renner, 1992; Hottelet et al., 1993) It has been applied successfully in various Alpine and Himalayan catchments (Braun et al., 2000). Altitude belts and four orientation classes (North, South, East, West) are used for semi-distributed computation in the snow and glacier routine. The glacier area is considered as a percentage of the area of each altitude belt and orientation class. A temperature-index method is used for the calculation of snow and ice melt as in $\mathrm{TAC}^{\mathrm{D}}$, whereas the computation of melt of debris-covered glaciers is treated the same way as of debrisfree glaciers. Therefore, HBV-ETH does not distinguish the different glacier surface conditions for melt water simulation as $\mathrm{TAC}^{\mathrm{D}}$ does. The soil routine and the runoff generation routine are not spatially distributed, thus treated as lumped. An upper (two outlets) and a lower (one outlet) storage for the entire catchment simulate the runoff generation. For the model comparison the same calibration and validation data sets were used. The calibration efforts for the HBV-ETH were at least similar to the ones for the $\mathrm{TAC}^{\mathrm{D}}$ model.

The comparison of the evaluation criteria (Table 5) shows that $\mathrm{TAC}^{\mathrm{D}}$ generally performs better. Figure 10 shows that the monsoon season in July and August 1994 is simulated reasonably well by both models. However, the HBV-ETH model underestimates the discharge both at the beginning of the monsoon season and during the post-monsoon season. These observations are typical for all simulated hydrological years.

It is difficult to compare the models due to their different spatial discretization. Therefore, Fig. 10 shows the output from the snow and glacier routine and the input into the runoff generation routine of $\mathrm{TAC}^{\mathrm{D}}$ as an average value of all HRUs and the storage levels related to the entire catchment for summer 1994. For the output from the snow and glacier routine HBV-ETH delivers higher values if precipitation contributes significantly to the composition of the output of the snow and glacier routine because there is no negative horizontal gradient for the calculation of basin precipitation as in $\operatorname{TAC}^{\mathrm{D}}$ (see Meteorological input data). Therefore, basin precipitation calculated by HBV-ETH is larger than the one calculated by $\mathrm{TAC}^{\mathrm{D}}$. At the beginning and at the end of the monsoon season more water is retained in the soil routine in the HBV-ETH model than in the $\mathrm{TAC}^{\mathrm{D}}$ model. The input into the runoff generation routine does not contribute to the filling of the upper storage of the HBV-ETH model until the middle of June 1994. The water is directed to the lower storage because the input into the upper storage is smaller than the percolation rate $(C P E R C)$ of $1.5 \mathrm{~mm} \mathrm{~d}^{-1}$. Therefore, the onset of discharge at the beginning of the monsoon season 


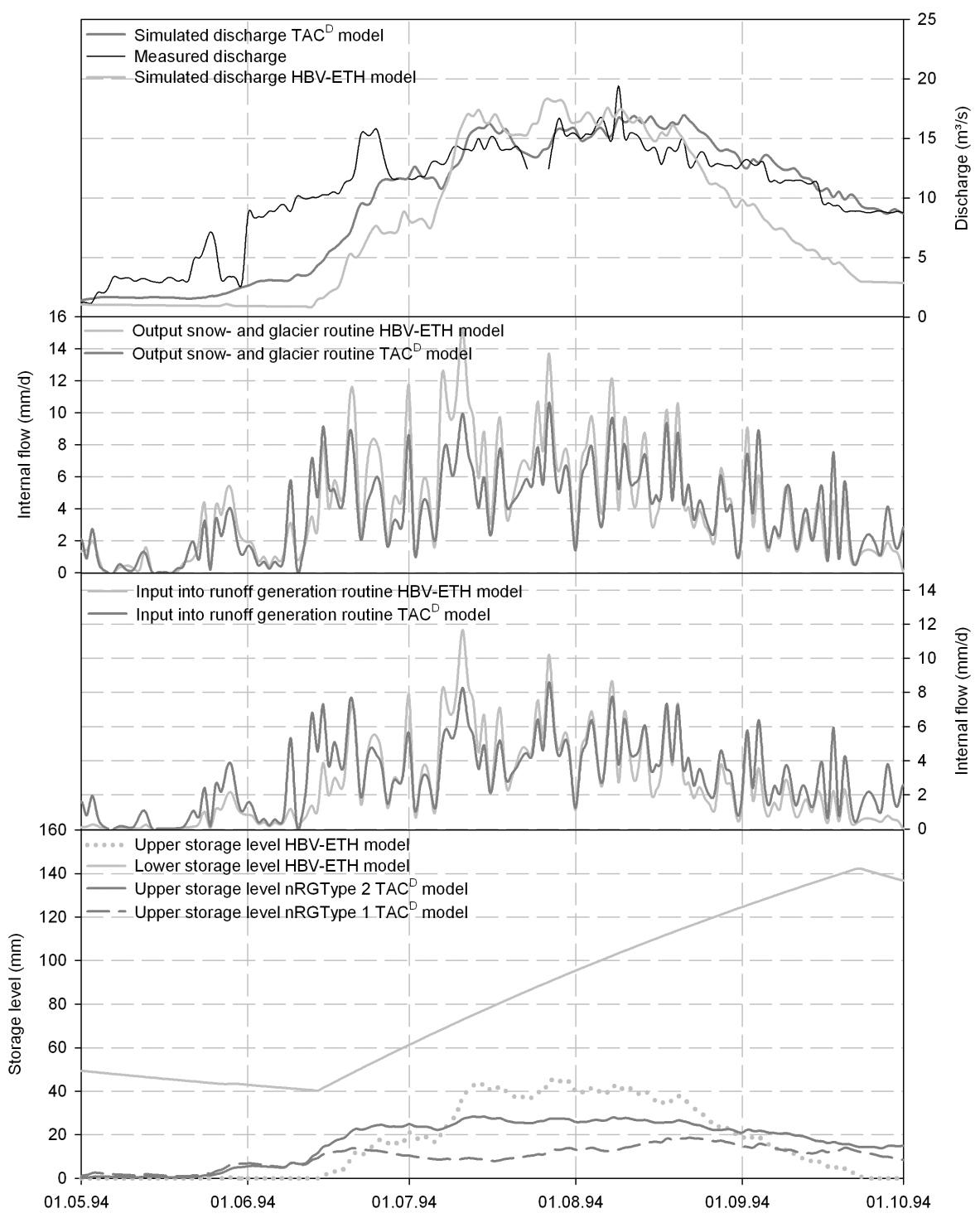

Fig. 10. Comparison of the modeling results of the HBV-ETH model and the TAC ${ }^{\mathrm{D}}$ model for summer 1994.

simulated by the HBV-ETH model is delayed more than the simulated discharge of the TAC ${ }^{\mathrm{D}}$ model. The upper storage of the HBV-ETH model is discharging continuously from the middle of August until the end of September 1994, whereas the upper storages of the $\mathrm{TAC}^{\mathrm{D}}$ model also contribute but remain more or less at the same level. This causes the fast decline of discharge simulated by the HBV-ETH model at the end of the monsoon season. The lower storage outflow of HBV-ETH maintains the winter discharge and the storage is recharged during the monsoon season. During the calibration of the HBV-ETH model it was realised that the model can either be calibrated to simulate the high flow season well or the low flow season in winter, but it was not possible to get a good simulation for the entire hydrological year. The more sophisticated and distributed runoff generation routine of $\mathrm{TAC}^{\mathrm{D}}$ enables the storage of water for maintaining the high winter discharge and at the same time simulating the discharge conditions of the monsoon season reasonably well.

To summarize, it can be stated that both models are applicable to the Langtang Khola catchment with success considering the assumptions and quality of the input. Both models are able to simulate the melting of ice and snow appropriately. The advantages of the TAC ${ }^{\mathrm{D}}$ model are the better redistribution of the water stored during monsoon season which resulted a better simulation of the onset of discharge in late spring and in better simulations of recession and low flow periods during the winter (Figs. 3 and 10). 


\section{Concluding remarks}

The study demonstrates a suitable way to simulate daily discharge values by incorporating basic process knowledge from remote Himalayan headwaters with limited data availability. The distributed, conceptual hydrological modified $\mathrm{TAC}^{\mathrm{D}}$ model has proven to be useful in such a datascarce, high-alpine region. The combination of statistical data pre-processing methods for temperature and precipitation with simple, robust modeling approaches enables a widely process-based, distributed simulation of the water balance what is a clear improvement to previous modeling efforts. In comparison to previous applications of conceptual precipitation-runoff models to the Langtang-Khola catchment, we are now able to simulate the entire annual hydrograph without empirical adjustments like the application of constant base flow values. The more process-based character of the newly introduced runoff generation and glacier routines enables the redistribution of water which is stored during monsoon season to simulate the relatively high winter discharge. The model uses topographical and physiographical information for the simulation of discharge and runoff generation processes to compensate for the lack of measurements, e.g. the use of calculated potential sunshine duration to compensate for the lack of further climatic stations in the catchment.

The analysis of the observed climate and discharge data together with the model application sharpened our questions for a number of needed process research studies in this environment: (i) The origin of the constant winter base flow needs to be better understood. In particular the role of groundwater versus melt water stored in the intra- and subglacial systems should be investigated using combined tracer and geophysical techniques. (ii) The role of redistribution of snow through and wind drift and avalanches that results in more snow in the lower valley need to be quantified. A combined remote sensing and ground mapping approach seems to be promising to observe the space and time variability of the snow cover. (iii) Additional, the role of frozen soil with regards to runoff generation processes (high flows and low flows) is poorly understoond. Also suitable ways to translate the related processes into the model space need to be developed.

Acknowledgements. The authors are grateful to SGHU staff, who collected and prepared the data. Further data was provided by ICIMOD, Nepal. The help of L. Wissmeier (ETH Lausanne, Switzerland) during model development is gratefully acknowledged. Finally, the authors wish to thank S. Maskey (UNESCO-IHE, Delft, The Netherlands) for critical comments on a previous version of the manuscript. The authors are grateful to the German IHP/HWRP National Committee for their financial support of the research work.

Edited by: A. Montanari

\section{References}

Alpenvereinskartographie: Alpenvereinskarte, Langthang HimalOst, No. 0/11, Austrian Alpine Club, 1990.

Bergström, S.: Development and application of a conceptual runoff model for Scandinavian catchments, Bull. Series A52, University of Lund, 134 pp., 1976.

Bergström, S.: The HBV-model - its structure and applications, SMHI Reports RH No. 4, Norrköping, Sweden, 1992.

Braun, L. N. and Aellen, M.: Modeling discharge of glacierized basins assisted by direct measurements of glacier mass balance, IAHS Publ. No. 193, 99-106, 1990.

Braun, L. N., Grabs, W., and Rana, B.: Application of a conceptual precipitation runoff model in the Langtang Khola basin, Nepal Himalaya, IAHS Publ. No. 218, 221-237, 1993.

Braun, L. N., Hottelet, Ch., Weber, M., and Grabs, W.: Measurement and simulation of runoff from Nepalese head watersheds, IAHS Publ. No. 248, 9-18, 1998.

Dam, J. C. van: Field-scale water flow and solute transport: SWAP model concepts, parameter estimation and case studies, Ph.D. Thesis, Wageningen Institute for Environment and Climate Research, Wageningen University, The Netherlands, 2000.

Fujita, K., Takeuchi, N., and Seko, K.: Glaciological observations of Yala Glacier in the Langtang Valley, Nepal Himalayas, 1994 and 1996, Bull. Glacier Res., 16, 75-81, 1998.

Grabs, W. and Pokhrel, A. P.: Establishment of a measuring service for snow and glacier hydrology in Nepal - conceptual and operational aspects, IAHS Publication No. 218, 3-16, 1993.

Heuberger, H., Masch, L., Preuss, E., and Schrocker, A.: Quaternary landslides and rock fusion in Central Nepal and in the Tyrolean Alps, Mountain Research and Development, 4, 345-362, 1984.

Hock, R.: A distributed temperature-index ice- and snowmelt model including potential direct solar radiation, J. Glaciol, 45(149), 101-111, 1999.

Hock, R: Temperature-index melt modelling in mountain areas, J. Hydrol., 282, 104-115, 2003.

Hottelet, Ch., Braun, L. N., Leibundgut, Ch., and Rieg, A.: Simulation of Snowpack and Discharge in an Alpine Karst Basin, IAHS Publ. No. 218, 249-260, 1993.

Jansson, P., Hock, R., and Schneider, T.: The concept of glacier storage: a review, J. Hydrol., 282, 116-129, 2002.

Karssenberg, D., Burrough, P. A., Sluiter, R., and de Jong, K.: The PC Raster software and course materials for teaching numerical modelling in the environmental sciences, Transactions in GIS, 5(2), 99-110, 2001.

Kattelmann, R.: Role of snowmelt in generating streamflow during spring in east Nepal, IAHS Publ. No. 218, 103-111, 1993.

Kayastha, R. B., Takeuchi, Y., Nakawo, M., and Ageta, Y.: Practical prediction of ice melting beneath various thickness of debris cover on Khumbu Glacier, Nepal, using a positive degree-day factor, IAHS Publ. No. 264, 71-81, 2000.

Kayastha, R. B.: Study of glacier ablation in the Nepalese Himalayas by the energy balance model and positive degree-day method, Ph.D. Thesis, Graduate School of Science, Nagoya University, 95 pp., 2001.

Klok, E. J., Jasper, K., Roelofsma, K. P., Gurtz, J., and Badoux, A.: Distributed hydrological modeling of a heavily glaciated Alpine river basin, Hydrological Sciences Journal - Journal Des Sciences Hydrologiques, 46, 553-570, 2001. 
Konz, M., Braun, L., Uhlenbrook, S., Shrestha, A.: Runoff from Nepalese Head Watersheds based on Measurements and Modelling, IHP/HWRP-Bericht, Heft 4, ISSN 1614-1180, 2006 a.

Konz, M., Braun, L., Uhlenbrook, S., Shrestha, A., and Demuth, S.: Regionalisation of a distributed catchment model for highly glacierized Nepalese headwatersheds, Proc. 5th FRIEND World Conference, Water resource variability: Processes, analyses and impacts, 27 November-1 December 2006, Havana, Cuba, IAHS Publ. 308, 454-465, 2006b.

Lang, H.: Is evaporation an important component in high alpine hydrology?, Nordic Hydrology, 12(4/5), 217-224, 1981.

Motoyama, H. and Yamada, T.: Hydrological observations in the Langtang Valley, Nepal Himalayas during 1987 monsoon - postmonsoon season, Bull. Glacier Res., 7, 195-201, 1989.

Nash, J. E. and Sutcliffe, J. V.: River flow forecasting through conceptual models, Part I - a discussion of principles, J. Hydrol., 10, 282-290, 1970.

O'Callaghan, J. F. and Mark, D. M.: The extraction of drainage networks from digital elevation data, Comput. Vision Graphics Image Process, 28, 328-344, 1984

Ono, Y.: Glacial fluctuations in the Langtang Valley, Nepal Himalaya, Göttinger Geographische Abhandlungen, 81, 31-38, 1986.

Ott, B. and Uhlenbrook, S.: Quantifying the impact of land use changes at the event and seasonal time scale using a processoriented catchment model, Hydrol. Earth Syst. Sci., 8(1), 62-78, 2004.

Popovnin, V. V. and Rozova, A. V.: Influence of sub-debris thawing on ablation and runoff of the Djankuat glacier in the Caucasus, Nord. Hydrol., 33(1), 75-94, 2002.

Ramage, C. S.: Monsoon meteorology, Academic Press, 1971.

Rana, B., Nakawo, M., Fukushima, Y., and Ageta, Y.: Runoff modelling of a river basin with a debris-covered glacier in Langtang Valley, Nepal Himalaya, Bull. Glacier Res., 14, 1-6, 1996.

Rango, A.: Worldwide testing of the snowmelt runoff model with application for predicting the effects of climate change, Nord. Hydrol., 23, 155-172, 1992.

Sakai, A., Fujita, K., and Kubota, J.: Evaporation and percolation effect on melting at debris-covered Lirung Glacier, Nepal Himalayas, 1996, Bull. Glacier Res., 21, 9-15, 2004.
Seko, K.: Seasonal variation of altitudinal dependence of precipitation in Langtang Valley, Nepal Himalayas, Bull. Glacier Res., 5, 41-47, 1987.

Shiraiwa, T., Ueno, K., and Yamada, T.: Distribution of mass input on glaciers in the Langtang Valley, Nepal Himalayas, Bull. Glacier Res., 10, 21-30, 1992.

Tarar, R. N.: Water resources investigation in Pakistan with the help of Landsat imagery-snow surveys, 1975-1978, IAHS Publ. No. 138, 177-190, 1982.

Uhlenbrook, S. and Leibundgut, Ch.: Process-oriented catchment modeling and multiple-response validation, Hydrol. Processes, 16, 423-440, 2002.

Uhlenbrook, S., Roser, S., and Tilch, N.: Development of a distributed, but conceptual catchment model to represent hydrological processes adequately in the meso scale, J. Hydrol., 291, 278296, 2004.

UNEP/ICIMOD: Inventory of glaciers, glacier lakes and glacier lake outburst floods monitoring and early warning systems in the Hindu Kush - Himalayan region [CD-ROM ISBN 929115359 1], 2002.

Verbunt, M., Gurtz, J., Jasper, K., Lang, H., Warnerdam, P., and Zappa, M.: The hydrological role of snow and glaciers in alpine river basins and their distributed modeling, J. Hydrol., 282, 3655,2003

Viviroli, D. and Weingartner, R.: The hydrological significance of mountains: from regional to global scale, Hydrol. Earth Syst. Sci., 8, 1016-1029, 2004, http://www.hydrol-earth-syst-sci.net/8/1016/2004/.

Weber, M.: Aspekte zur Extrapolation von Tagesmittelwerten von Temperatur und täglichen Niederschlagssummen an hochgelegenen Gebirgsstationen aus Klimadaten des örtlichen Klimamessnetzes in Nepal, internal report Bavarian Academy of Sciences, Commission of Glaciology, Munich, 1997.

Zappa, M., Pos, F., Strasser, U., Warmerdam, P., and Gurtz, J.: Seasonal water balance of an alpine catchment as evaluated by different methods for spatial distributed snowmelt modeling, Nord. Hydrol., 34(3), 179-202, 2003.

Zingg, Th.: Beziehung zwischen Temperatur und Schmelzwasser und ihre Bedeutung für Niederschlags- und Abflussfragen, IAHS Publ. No. 32, 266-269, 1951. 